\title{
PENERAPAN MODEL PEMBELAJARAN KONSTEKTUAL UNTUK MENINGKATKAN KOMPETENSI SISWA DALAM PEMECAHAN MASALAH MATEMATIKA PADA POKOK BAHASAN LINGKARAN
}

\author{
JONIH ISKANDAR \\ Pascasarjana PMIPA, Universitas Indraprasta PGRI, Jakarta \\ e-mail: jonskandar@gmail.com
}

\begin{abstract}
ABSTRAK
Penelitian ini bertujuan untuk memperoleh gambaran tentang penerapan model konstektual pada pembelajaran matematika dalam upaya meningkatkan kompetensi siswa. Subjek dalam penelitian ini adalah siswa kelas VIII A Mts. Tunas Harapan Bangsa Kabupaten Sukabumi, berjumlah 41 orang yang terdiri dari 21 siswa laki-laki dan 20 siswa perempuan dan sub pokok bahasan adalah lingkaran. Hal ini dapat dilhat dari nilai rata-rata tes formatif setiap siklus tindakan dan sub sumatif, yaitu Siklus Tindakan I rata-ratanya adalah 66,88 dengan ketuntasan $70,73 \%$, pada Siklus Tindakan II rata-ratanya adalah 73,66 dengan ketuntasan 87,80\%, dan pada sub Sumatif rata-ratanya 88 dengan ketuntasan $92,68 \%$. Selain untuk meningkatkan hasil belajar siswa, penggunaan pendekatan konstektual pun dapat meningkatkan respon siswa yang terjaring melalui jurnal dan angket. Sebagai siswa merespon positif terhadap pembelajaran dengan menggunakan metode pendekatan konstektual. Berdasarkan angket siswa diperoleh respon sebesar 3,09. Sedangkan berdasarkan jurnal, pada Siklus I, II, dan III siswa memberikan respon positif berturut-turut sebesar 53,66\%, 65,86\%, dan 87,80\%.
\end{abstract}

Kata Kunci : Model Pembelajaran Konstektual, Pemecahan Masalah, Kompetensi Siswa

\section{ABSTRACT}

This study aims to obtain an overview of the application of contextual models in mathematics learning in an effort to improve student competence. The subjects in this study were students of class VIII A Mts. Tunas Harapan Bangsa, Sukabumi Regency, found 41 people consisting of 21 male students and 20 female students and the sub-topics were circles. This can be seen from the average value of the formative tests for each cycle of action and sub summative, namely the Action Cycle I on average is 66.88 with $70.73 \%$ completeness, in Cycle II the average is 73.66 with 87 completeness. $.80 \%$, and in the sub-summative the average is 88 with a completeness of $92.68 \%$. In addition to improving student learning outcomes, the use of a contextual approach can also increase the responses of students who are netted through journals and questionnaires. As students respond positively to learning by using a contextual approach. Based on student questionnaires, a response of 3.09 was obtained. Meanwhile, based on the journal, in Cycles I, II, and III students gave positive responses of 53.66\%, 65.86\%, and $87.80 \%$, respectively.

Keywords: Contextual Learning Model, Problem Solving, Student Competence

\section{PENDAHULUAN}

Seperti halnya dengan fenomena disekolah yang akan penulis jadikan penelitian pembelajaran yang kompeten untuk materi judul skripsi di atas penulis juga mengambil alasan tertentu yaitu nilai matematika kelas VIII di sekolah tersebut masih tergolong minimum dengan rata-rata 4,9 (rekapitulasi nilai matematika semester ganjil tahun pelajaran 2009/2010). Selanjutnya penulis berkeinginan ingin merubah paradigma proses pembelajaran masih didominasi oleh guru, siswa hanya duduk terdiam menerima pengetahuan baru yang diberikan oleh guru tanpa bisa mencari dan menemukan sendiri pengetahuan yang baru tersebut.

Guru seharusnya bersifat sebagai fasilitator, dan motivator yang mengarahkan siswa untuk mencari dan menemukan pengetahuan sendiri. Kebanyakan siswa datang kesekolah tidak dengan persiapan untuk menghadapi pelajaran yang akan diterimanya. Untuk itu penulis 
berharap setelah selesainya penelitian yang mampu mengeluarkan ide kreatif supaya siswa tidak hanya duduk terdiam tetapi aktif adalam proses pembelajaran.

Penulis selaku calon tenaga pendidik sangat tergugah untuk bisa merubah fenomena yang masih tidak sesuai dengan tuntutan masyarakat akan tenaga kependidikan terutama guru, kemudian juga memberikan motivasi kepada penulis supaya benar-benar mempunyai dampak pendidikan yang memiliki utilitas atau daya guna lulusan yang mampu memasuki dunia kerja khususnya dalam bidang pendidikan.

Dilembaga pendidikan formal (formal education) ini, guru menjalankan tugas pokok dan fungsi yang bersifat multiperan, yaitu sebagai pendidik, pengajar dan pelatih. Kehadiran guru sangat terasa esensi dan urgensinya pada pendidikan formal untuk setiap jenis dan jenjang. Pengajar merujuk pada pembinaaan dan pengembangan pengetahuan atau asah otak intelektual.

Model pembelajaran yang dianggap memenuhi syarat tersebut adalah model pembelajaran konstektual (Sumiati:13-18). Sehingga model ini tidak bertentangan dengan sifat guru yang seharusnya hanya sebagai fasilitator dan motivator yang mengarahkan siswa untuk mencari dan menemukan sendiri pengetahuan baru. Belajar konstektual siswa terlibat aktif pada proses pembelajaran, sehinga memberikan dampak yang positif terhadap interaksi dan komunikasi yang berkualitas, dan memotivasi siswa sehingga dapat meningkatkan prestasi hasil belajarnya.

Model pembelajaran konstektual pada awalnya dikembangkan oleh Jhon Dewey tahun 1918 dalam Sumiati (2008:14). Model pembelajaran konstektual merupakan konsep belajar yang membantu guru mengaitkan antara materi pembelajaran yang diajarkan dengan situasi dunia nyata dan mendorong siswa untuk membantu hubungan antara pengetahuan yang dimiliki dengan penerapannya dalam kehidupan mereka sehari-hari. Dengan demikian metode pembelajarn konstektual mengutamakan pada pengetahuan dan pengalaman atau dunia nyata (real word leraninf) berpikir tingkat tinggi berpusat pada siswa, siswa aktif, kritis, memecahkan masalah, siswa belajar menyenangkan, mengasikan, tidak membosankan (joyfull and quantum learning) dan menggunakan berbagai sumber belajar.

Dari uraian diatas bahwa model pembelajaran konstektual merupakan model pembelajaran yang sangat tepat untuk digunakan dalam setiap pelajaran di kelas khususnya pelajaran matematika, karena dengan pembelajaran matematika ini siswa dapat lebih memperkaya pengalamannya dalam menyelesaikan setiap permasalahan yang dihadapi secara bersama-sama.

Mengingat hipotesis tadi, penulis tertarik untuk melakukan Penelitian Tindakan Kelas (PTK) dengan tujuan untuk mengumpulkan informasi, dan fakta yang sebanyak-banyaknya mengenai rendahnya nilai matematika semester ganjil yang masih minimum dengan rata-rata 4,9. Sehingga penulis dapat menentukan solusi yang tepat untuk mengatasinya dan kemudian pembelajaran menjadi dapat ditingkatkan secara maksimal, yang tentu ditunjukan dengan meningkatnya hasil belajar siswa. Untuk itu penulis berkeinginan untuk melakukan Penelitian Tindakan Kelas (PTK) dengan judul "Penerapan Model Pembelajaran Konstektual Untuk meningkatkan Kompetensi Siswa Dalam Pemecahan Masalah Matematika" Penelitian Tindakan Kelas (PTK) pada materi lingkungan di kelas VIII-A Mts. Tunas Harapan Bangsa Kecamatan Nyalindung Kabupaten Sukabumi.

\section{METODE PENELITIAN}

Penelitian ini dilakukan di sukabumi, tepatnya pada Mts. Tunas Harapan Bangsa Kabupaten sukabumi, dengan memfokuskan penelitian pada siswa yang sedang belajar materi lingkaran yaitu siswa kelas VIII-A. Model pembelajaran yang di gunakan adalah model pembelajaran kontekstual. Pembelajaran kontekstual merupakan konsep belajar yang membantu guru mengaitkan antara materi pembelajaran yang di ajarkan dengan situasi dunia nyata siswa dan mendorong siswa membuat hubungan antara pengetahuan yang dimilikinya dengan penerapannya dalam kehidupannya sehari-hari. Sumyati (2008: 13-18). Penelitian ini merupakan Penelitian Tindakan Kelas (PTK) (classroom atction research), yaitu "Penelitian 
yang dilakukan guru di dalam kelasnya sendiri melalui refleksi diri, dengan tujuan memperbaiki kinerjanya sebagai guru, sehingga hasil belajar siswa semakin meningkat". Wardani (2006: 21.22) yang mengacu pada teori PTK menurut Kurt Lewi. Zaenal (2008: 21.22) yang menyatakan bahwa dalam satu siklus terdiri dari empat langkah kegiatan yaitu: (1) Perencanaan (Planning), (2) Aksi atau tindakan-tindakan (Action), (3) Observasi (Observation), (4) Refleksi (Reflecting).

\section{HASIL DAN PEMBAHASAN}

\section{Hasil}

Sebelum penelitian ini dilaksanakan, peneliti terlebih dahulu melakukan orientasi lapangan dan observasi awal untuk memperoleh informasi atau permasalahan yang berhubungan dengan proses belajar mengajar matematika dan selanjutnya membuat perencanaan tindakan pembelajaran.

Berdasarkan hasil orientasi dan observasi awal diperoleh keterangan bahwa proses pembelajaran dikelas selama ini, khususnya pada teknik penyampaian materi-materi tertentu disesuaikan dengan situasi serta kondisi siswa.

Pada dasarnya belum menerapkan pembelajaran matematika dengan pendekatan konstektual yang akan diterapkan dalam penelitian sebagai upaya meningkatkan hasil belajar siswa dan setelah peneliti menjelaskan guru merasa tertarik dengan pembelajaran menggunakan pendekatan konstektual terutama untuk materi lingkungan karena banyak contoh-contoh soal lingkungan dapat diambil dari kehidupan nyata sehari-hari. Dan dianggap siswa akan lebih aktif dalam Kegiatan Belajar Mengajar (KBM) dan lebih memahami materi yang dipelajari.

Tindakan yang dilakukan pada setiap siklus pembelajaran disesuaikan dengan rencana pembelajaran yang telah dibuat. Kegiatan selama berlangsungnya pembelajaran pada pokok bahasan lingkaran terdiri dari tiga siklus tindakan.

\section{Analisis Hasil}

1. Analisis Hasil Belajar

Analisis hasil belajar siklus tindakan ini diperoleh dari hasil tes formatif yang dilaksanakan pada akhir proses pembelajaran untuk setiap siklusnya.

Tabel 1 Tes Kognitif Siswa

\begin{tabular}{|c|c|c|c|c|c|c|}
\hline \multirow{2}{*}{ Jenis Teks } & \multicolumn{3}{|c|}{ Nilai } & KKM & Tuntas & $\begin{array}{c}\text { Tidak } \\
\text { Tuntas }\end{array}$ \\
\cline { 2 - 4 } & Tertinggi & Terendah & Rata-rata & & & 12 \\
\hline Siklus I & 82 & 58 & 68,88 & 65 & 29 & 9 \\
\hline Siklus II & 90 & 58 & 78,05 & 65 & 32 & 9 \\
\hline Siklus III & 92 & 60 & 80,63 & 65 & 36 & 5 \\
\hline Sub Sumatif & 60 & 64 & 88 & 65 & 38 & 3 \\
\hline
\end{tabular}

\section{GERAFIK TES KOGNITIF SISWA}

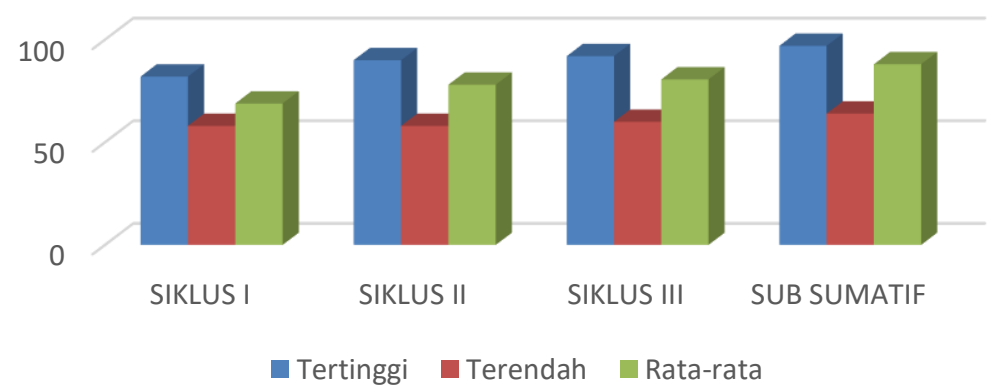

Gambar 1. Tes Kognitif Siswa 
2. Analisis Jurnal Siswa

Jurnal berisi tentang kesan, tanggapan siswa setelah pembelajaran siklus tindakan untuk memperoleh gambaran terhadap pembelajaran matematika dalam upaya perbaikan pada pembelajaran.

Tabel 2 Presentase Respon Siswa Untuk Setiap Siklus

\begin{tabular}{|c|c|c|c|}
\hline \multirow{2}{*}{ Jenis Komentar } & \multicolumn{3}{|c|}{ Persentase } \\
\cline { 2 - 4 } & Siklus I & Siklus II & Siklus III \\
\hline Positif & $53,66 \%$ & $65,86 \%$ & $87,80 \%$ \\
\hline Negatif & $24,30 \%$ & $19,51 \%$ & $7,32 \%$ \\
\hline Biasa & $21,95 \%$ & $14,63 \%$ & $4,88 \%$ \\
\hline
\end{tabular}

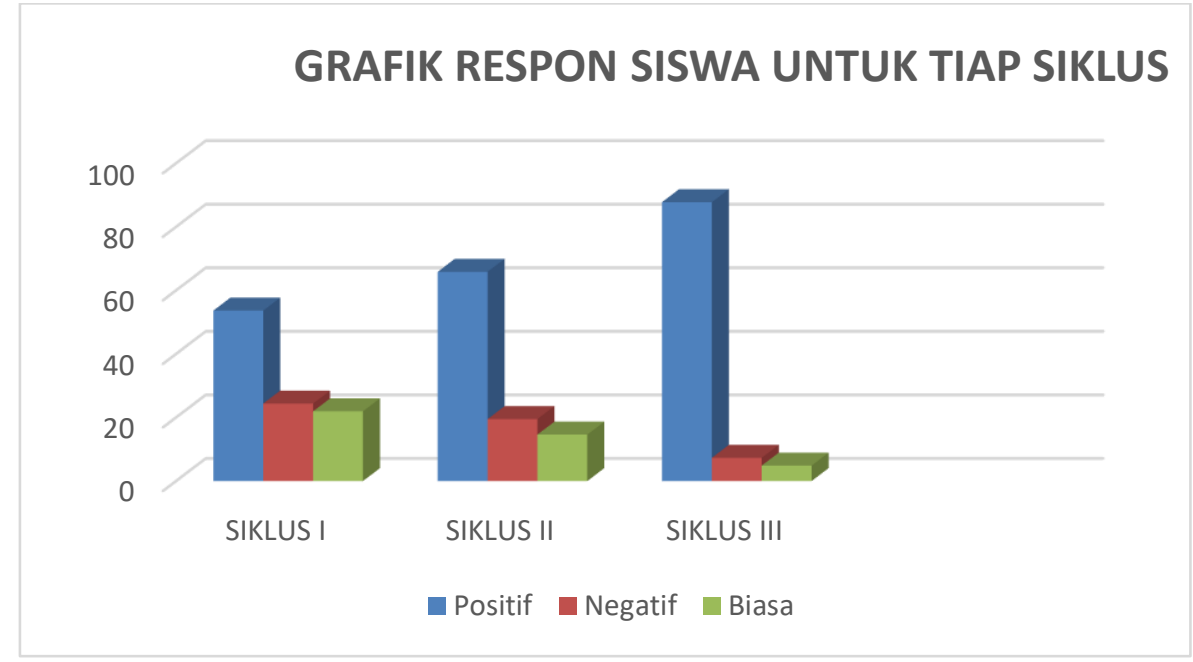

Gambar 2. Respon Siswa Setiap Siklus

3. Analisis Angket Siswa

Setelah pembelajaran siklus tiga selesai dilaksanakan, siswa diberi daftar isian untuk mengetahui sikap mereka setelah pembelajaran konstektual. Dari 41 siswa yang menjadi subjek penelitian, semua siswa mengisi angkat, secara lengkap persentase sikap siswa dalam pembelajaran.

\section{Pembahasan}

Hasil belajar siswa dilihat dari nilai-nilai rata-rata tes formatif setiap siklus Tindakan dan Sumatif, yaitu Siklus Tindakan I rata-ratanya 68,88 dengan ketuntasan 70,73\%, pada Siklus Tindakan II rata-ratanya 73,63 dengan ketuntasan 78,05\%, pada Siklus Tindakan III rataratanya 80,63 dengan ketuntasan $87,80 \%$, dan pada tes Sumatif rata-ratanya 88 dengan ketuntasan $92,86 \%$.

Tabel 3 Hasil Belajar Siswa

\begin{tabular}{|c|c|c|c|c|c|}
\hline \multirow{2}{*}{ Hasil Belajar } & \multicolumn{4}{|c|}{ Jenis Tes } & \multirow{2}{*}{ Rata-rata } \\
\cline { 2 - 5 } & Formatif I & Formatif II & Formatif III & Sub Sumatif & \\
\hline Nilai Rata-rata & 68,88 & 73,66 & 80,63 & 88 & 77,79 \\
\hline DSS (\%) & 70,73 & 78,05 & 87,80 & 92,86 & 82,32 \\
\hline
\end{tabular}

Dari data setiap siklus dan sub sumatif maka dapat disimpulkan bahwa pembelajaran matematika melalui pendekatan konstektual pada poko bahasan lingkaran dapat meningkatkan kompetensi siswa dalam pemecahan masalah matematika. Berdasarkan tabel di atas diperoleh data bahwa daya serap untuk setiap siklus tindakan terjadi peningkatan dan rata-rata daya serap kelas pada pokok bahasan lingkaran dengan menggunakan pendekatan konstektual sesuai dengan harapan. 
Berdasarkan hasil peneliti, dilihat dari hasil observasi, jurnal dan angket dapat disimpulkan bahwa pembelajaran dengan menggunakan pendekatan konstektual pada pokok bahasan lingkaran mendapat respon yang positif dari persentase rata-rata angket, bahwa respon siswa pada pembelajaran dengan menggunakan pendekatan konstektual positif dengan rata-rata 3,09 .

Dari artikel jurnal Penerapan Pendekatan Kontekstual Untuk Meningkatkan Hasil Belajar Siswa Pada Mata Pelajaran IPA Kelas III Madrasah Ibtidaiyah Al-Hikmah Tolitoli (2014) serta jurnal Penerapan model pembelajaran contextual teaching and learning (CTL) untuk meningkatkan Motivasi Belajar ipa siswa kelas II SDN02 Gambir Manis Pracimantoro Wonogiri (2016). Maka, pengaruh model pembelajaran Kontekstual dan Contextual Teaching and Learning (CTL) pada peningkatan prestasi siswa terbukti efektif. Keefektifan dari penerapan model pembelajaran Contextual Teaching and Learning (CTL) tersebut terlatak pada hubungan model Contextual Teaching and Learning (CTL) untuk meningkatkan hasil belajar siswa. Model pembelajaran Contextual Teaching and Learning (CTL) menciptakan pembelajaran menuntut siswa aktif dan turut serta dalam mengikuti pembelajaran.

Peningkatan terjadi karena siswa mengalami pembelajaran, beraktivitas sendiri untuk memperoleh pengalaman, pengetahuan, pemahaman dan tingka laku lainnya, tidak hanya membaca atau mendengarkan ceramah oleh pendidik sehingga aktivitas dan hasil belajar mereka meningkat. Hal ini sesuai dengan hasil penelitian yang dilakukan konsisten dengan hasil penelitian yang dilakukan oleh peneliti-peneliti yang terdahulu.

\section{KESIMPULAN}

Berdasarkan hasil analisis dan temuan peneliti yang diperoleh selama pembelajaran lingkaran yang dilaksanakan dalam 3 siklus, diperoleh kesimpulan sebagai berikut:

1. Berdasarkan analisis tes formatif setiap akhir siklus, pada umumnya meningkat. Hal ini dapat dilihat dari hasil peningkatan penguasaan siswa setiap siklus yang semakin membaik. Data memperlihatkan bahwa tingkat penguasaan rata-rata siswa pada setiap tes secara berturut-turut, tes formatif I nilai rata-rata tingkat penguasaan siswa 68.88 sedangkan untuk daya serap kelas $70.73 \%$, tes formatif II nilai rata-rata tingkat penguasaan siswa 73.66 sedangkan untuk daya serap kelas $78.05 \%$, tes formatif III nilai rata-rata tingkat penguasaan siswa 80.63 sedangkan untuk daya serap kelas $87.80 \%$, dan tes sumatif rata-rata tingkat penguasaan siswa 88 sedangkan untuk daya serap kelas adalah $92.68 \%$.

2. Dari hasil jurnal dan angket siswa yang dilakukan selama proses belajar mengajar menunjukan bahwa penerapan pembelajaran konstektual dapat meningkatkan kompetensi siswa dalam pemecahan masalah matematika. Dalam hal ini siswa dapat berperan aktif dan bersosialisasi dengan baik. Kemudian siswa sangat antusias dalam belajar dan dapat mencerna materi pelajaran dengan baik, sehingga materi pelajaran mudah diingat dan mudah dipahami. Dengan demikian secara keseluruhan sikap siswa terhadap pembelajaran matematika dengan menggunakan pendekatan konstektual berpengaruh positif.

\section{DAFTAR PUSTAKA}

Adi, Mestawaty. (2014). Penerapan Pendekatan Kontekstual Untuk Meningkatkan Hasil Belajar Siswa Pada Mata Pelajaran Ipa Kelas III Madrasah Ibtidaiyah Al-Hikmah Tolitoli. Jurnal Kreatif Tadulako Online

Aqib, Zainal. (2004) Penelitian Tindakan Kelas. Bandung: CV. YRAMA WIDYA

Danim, Sudarwan. (2002). Inovasi Pendidikan. Bandung: CV. Pustaka Setia

Haryani, D. (2011). Pembelajaran Matematika Dengan Pemecahan Masalah Untuk Menumbuhkembangkan Kemampuan Berpikir Kritis Siswa. Prosiding Seminar Nasional. Penelitian, Pendidikan dan Penerapan MIPA, 121-126. 
Huda, Miftahul. (2013). Model-model Pengajaran dan Pembelajaran. Yogyakarta: Pustaka Belajar

Permata, R. D. (2016). Upaya meningkatkan kemampuan pemecahan masalah matematika melalui pendekatan contextual teaching and learning (CTL) siswa kelas VIII-A

Sumartini, T. S. (2016). Peningkatan Kemampuan Pemecahan Masalah Matematika Siswa melalui Pembelajaran Berbasis Masalah. Jurnal Pendidikan Matematika,

Sumiati. (2008). Metode Pembelajaran. Bandung: CV Wacana Primata.

Sudjana. (2001). Metode dan Teknik Pembelajaran Partisipatif. Bandung: Falah Production

Suprayeti. (2003). Pembaharuan Pembelajaran. Jakarta: Universitas Terbuka

Tutut, Rahmawati. (2018). Penerapan Model Pembelajaran CTL untuk Meningkatkan Hasil

Belajar Siswa Sekolah Dasar Pada Mata Pelajaran IPA. Jurnal Ilmiah Pendidikan dan Pembelajaran PPs Universitas Pendidikan Ganesha

Winataputra, Udin S. (2007). Teori Belajar dan Pembelajaran. Jakarta: Universitas Terbuka

Wardani, Igak. (2007). Penelitian Tindakan Kelas (PTK). Jakarta: Universitas Terbuka

Wiriatmaja, Rochiati. (2005). Metode Penelitian Tindakan Kelas. Bandung: PT. Remaja Rosdakarya

.... Departemen Pendidikan Nasional. (2007). Model Silabus dan Rencana Pelaksanaan Pembelajaran 